\title{
REMOVAL KADAR BESI (Fe) DALAM AIR BERSIH SECARA SPRAY AERATOR DISERTAI PEMBUBUHAN KAPORIT
}

\author{
Oleh : Joko Sutrisno *)
}

\begin{abstract}
Abstrak
Berbagai sumber air bersih yang dipergunakan masyarakat sebagai sumber air bersih diantaranya adalah air tanah dangkal. Untuk di daerah perdesaan umumnya untuk memperoleh air dibuatlah sumur gali karena cara pembuatannya mudah dan dengan biaya yang relatif murah. Salah satu syarat air bersih yang berkualitas adalah kandungan kadar besi ( $\mathrm{Fe}$ ) yang ada dalam air bersih adalah $1 \mathrm{mg} / \mathrm{liter}$. Untuk air bersih dengan kadar besi ( $\mathrm{Fe}$ ) 4,045 mg/liter dapat diremoval dengan aerasi secara spray aerator dengan pembubuhan kaporit.

Rumusan masalah dalam penelitian ini adalah berapa penurunan kadar besi (Fe) yang terkandung dalam air sampel dengan penambahan kaporit sebelum dan sesudah dilakukan aerasi secara sprayer aerator dan Apakah ada perbedaan penurunan kadar besi (Fe) dalam air bersih antara tahap pertama (nozel berdiamer 1,2 $\mathrm{mm}$ dan 1,5 $\mathrm{mm}$ dengan dosis kaporit masing - masing $5 \mathrm{mg} /$ liter) dan tahap kedua (nozel diamter 1,2 $\mathrm{mm}$ dan 1,5 mm, dengan kaporit $10 \mathrm{mg} / \mathrm{liter}$ ). Tujuannya adalah Untuk mengetahui kadar besi ( $F e)$ yang terkandung dalam air bersih sampel dengan penambahan kaporit sebelum dan sesudah aerasi secara spray aerator. Menganalisis aplikasi penambahan kaporit yang digunakan untuk meremoval kadar besi (Fe) secara sparay aerator. Apakah ada perbedaan penurunan kadar besi ( $F e$ ) antara nozel berdiamer 1,2 $\mathrm{mm}$ dengan dosis kaporit masing-masing $5 \mathrm{mg} /$ liter, dan $10 \mathrm{mg} / \mathrm{liter}$ dengan nozel berdiameter 1,5 $\mathrm{mm}$ dengan dosis kaporit masing -masing $5 \mathrm{mg} /$ liter dan $10 \mathrm{mg} /$ liter. Manfaatnya adalah Memberikan informasi bagi kalangan akademis, dan penelitian lanjutan dikemudian hari mengenai efektifitas spray aerator setelah diberi perlakuan berupa pembubuhan kaporit. Sebagai sumbangan pemikiran tentang pentingnya pengolahan air bersih dengan kadar besi $(\mathrm{Fe})$ yang cukup tinggi. Mendapatkan alternatif teknologi pengolahan air bersih yang diharapkan dapat diterapkan untuk mengatasi kadar besi ( $F e$ ) yang ada dalam air tanah.

Hasil yang di peroleh dalapm penelitian ini adalah kadar besi (Fe) air bersih sebelum dilakukan removal secara spray aerator mula - mula 4,045 mg/liter, dan untuk sampel tahap pertama dengan pembubuhan kaporit $5 \mathrm{mg} / \mathrm{liter}$, menunjukan angka 3,190 mg/liter Sedangkan setelah dilakukan aerasi secara spray aerator melalui nozel $\varnothing ~ 1,2 \mathrm{~mm}$ mampu meremoval kadar besi ( $\mathrm{Fe}$ ) dalam air rata-rata 1,3970 $\mathrm{mg} /$ liter, dan melalui nozel Ø 1,5 $\mathrm{mm}$ rata-rata 1,1426 $\mathrm{mg} /$ liter. Untuk removal kadar besi $(\mathrm{Fe})$ tahap ke dua dengan nozel 1,2 $\mathrm{mm}$ kaporit $10 \mathrm{mg} /$ liter rata-rata $1,210 \mathrm{mg} /$ liter, dengan nozel 1,5 mm rata - rata 1,1982 $\mathrm{mg} /$ liter dan adanya perbedaan penurunan kadar besi $(\mathrm{Fe})$ air bersih yang signifikan setelah dilakukan aerasi secara spary aerator tahap pertama dan kedua Yaitu : a). Kadar besi (Fe) air bersih sebelum dilakukan perlakuan sebesar 4,045 mg/liter. b). Kadar besi ( $F e$ ) air bersih tahap pertama dengan pembubuhan kaporit $5 \mathrm{mg} / \mathrm{liter}$ sebelum diaerasi sebesar 3,0190 mg/liter, setelah dilakukan aerasi menggunakan nozel diameter $1,2 \mathrm{~mm}$ rata - rata $1,3970 \mathrm{mg} /$ liter dan diameter nozel $1,5 \mathrm{~mm}$ rata-rata $1,1426 \mathrm{mg} /$ liter. c). Kadar besi ( $\mathrm{Fe}$ ) air bersih tahap kedua setelah pembubuhan kaporit $10 \mathrm{mg} / \mathrm{liter}$ sebelum diaerasi sebesar 3,494 mg/liter, setelah dilakukan aerasi menggunakan nozel diameter 1,2 $\mathrm{mm}$ rata-rata 1,2102 $\mathrm{mg} / \mathrm{liter}$, dan nozel diameter $1,5 \mathrm{~mm}$ rata - rata 1,1982 $\mathrm{mg} / \mathrm{liter}$.
\end{abstract}

Kata Kunci: Air Tanah, Kadar Besi, Aerasi, Spray Aerator,Klorin, Kaporit

\section{PENDAHULUAN \\ Latar Belakang}

Salah satu upaya pemenuhan air bersih bagi masyarakat pada masa sekarang maupun di masa yang akan datang adalah melalui proses pengolahan air bersih dengan tujuan mengolah air baku dari sumber tertentu, seperti ditetapkan dalam Peraturan menteri Kesehatan Republik Indonesia Nomor 416/MENKES/PER/IX/1990 tanggal 3 September 1990 tentang syarat-syarat dan pengawasan kualitas air. Salah satu persyaratan kualitas adalah kadar besi $(\mathrm{Fe})$ sebesar $0,3 \mathrm{mg} / \mathrm{liter}$. Bila syarat-syarat tersebut tidak diperhatikan maka selanjutnya akan menimbulkan masalah seperti gangguan kesehatan, gangguan estetika, dan gangguan terhadap sarana-sarana air bersih. Gangguan dari estetika misalnya warna coklat kekuning-kuningan, bau yang tidak sedap sedang gangguan terhadap

\footnotetext{
*) Dosen Teknik Lingkungan

Universitas PGRI Adi Buana Surabaya
} 
sarana air bersih yaitu alat-alat seperti closet, washtafel, bak mandi, pakaian menunjukan kotor dan warna coklat serta berkaratnya sarana air bersih seperti kran, pipa dan pompa yang terbuat dari besi. Gangguan tersebut diatas disebabkan oleh salah satu zat seperti besi (Fe) yang kadarnya tinggi. Dalam air bersih standar maksimum kadar besi ( $\mathrm{Fe}$ ) adalah $1 \mathrm{mg} /$ liter (Sugiharto, 1983). Tingginya kadar besi dalam air disebabkan oleh banyak faktor tergantung dari sumber air itu, salah satu faktor tersebut adalah struktur batuan yang dilalui oleh air banyak mengandung besi (Fe).

Berbagai sumber air bersih yang dipergunakan masyarakat sebagai sumber air bersih diantaranya adalah air tanah dangkal. Untuk di daerah perdesaan umumnya untuk memperoleh air dibuatlah sumur gali karena cara pembuatannya mudah dan dengan biaya yang relatif murah Salah satu syarat air bersih yang berkualitas adalah kandungan kadar besi ( $\mathrm{Fe}$ ) yang ada dalam air bersih adalah $1 \mathrm{mg} / \mathrm{liter}$. Untuk air bersih dengan kadar besi (Fe) 4,045 mg/liter dapat diremoval dengan aerasi secara spray aerator dengan pembubuhan kaporit.

\section{Batasan dan Ruang Lingkup Penelitian}

Batasan dalam penelitian ini adalah sebagai berikut :

1. Air yang digunakan dalam penelitian ini adalah air bersih yang berasal dari sumur gali.

2. Untuk proses aerasi digunakan nozel ukuran yang berbeda sebagi alat sprayer dengan diameter $1,2 \mathrm{~mm}$ dan $1,5 \mathrm{~mm}$.

3. Parameter yang dianalisis dalam penelitian ini adalah :

a. Kadar Besi (Fe) air bersih dibubuhi kaporit dengan dosis $5 \mathrm{mg} / \mathrm{l}$ dan 10 $\mathrm{mg} /$ liter, sebelum proses aerasi secara spray Aerator.

b. Kadar besi $(\mathrm{Fe})$ air bersih dibubuhi kaporit dengan dosis $5 \mathrm{mg} / \mathrm{l}$ dan 10 $\mathrm{mg} /$ liter. setelah proses aerasi secara Spray Aerator.

\section{Rumusan Masalah}

1. Berapa penurunan kadar besi $(\mathrm{Fe})$ yang terkandung dalam air sampel dengan penambahan kaporit sebelum dan sesudah dilakukan aerasi secara sprayer aerator?

2. Apakah ada perbedaan penurunan kadar besi $(\mathrm{Fe})$ dalam air bersih antara tahap pertama (nozel berdiamer 1,2 mm dan $1,5 \mathrm{~mm}$ dengan dosis kaporit masing - masing $5 \mathrm{mg} /$ liter) dan tahap kedua (nozel diamter 1,2 $\mathrm{mm}$ dan 1,5 $\mathrm{mm}$, dengan kaporit $10 \mathrm{mg} /$ liter) ?

\section{Tujuan Penelitian}

1. Untuk mengetahui kadar besi $(\mathrm{Fe})$ yang terkandung dalam air bersih sampel dengan penambahan kaporit sebelum dan sesudah aerasi secara spray aerator.

2. Menganalisis aplikasi penambahan kaporit yang digunakan untuk meremoval kadar besi (Fe) secara sparay aerator.

3. Apakah ada perbedaan penurunan kadar besi ( $\mathrm{Fe})$ antara nozel berdiamer $1,2 \mathrm{~mm}$ dengan dosis kaporit masingmasing $5 \mathrm{mg} /$ liter, dan $10 \mathrm{mg} / \mathrm{liter}$ dengan nozel berdiameter $1,5 \mathrm{~mm}$ dengan dosis kaporit masing -masing 5 $\mathrm{mg} /$ liter dan $10 \mathrm{mg} / \mathrm{liter}$.

\section{Manfaat Penelitian}

1. Memberikan informasi bagi kalangan akademis, dan penelitian lanjutan dikemudian hari mengenai efektifitas spray aerator setelah diberi perlakuan berupa pembubuhan kaporit.

2. Sebagai sumbangan pemikiran tentang pentingnya pengolahan air bersih dengan kadar besi $(\mathrm{Fe})$ yang cukup tinggi.

3. Mendapatkan alternatif teknologi pengolahan air bersih yang diharapkan dapat diterapkan untuk mengatasi kadar besi $(\mathrm{Fe})$ yang ada dalam air tanah.

\section{KAJIAN PUSTAKA}

\section{A. Kadar Besi ( $\mathrm{Fe}$ ) dalam Air}

Besi adalah salah satu elemen kimia yang dapat ditemui pada hampir setiap tempat di bumi, pada semua lapisan geologis dan badan air. Pada umumnya, besi yang ada di dalam air dapat bersifat :

a. Terlarut sebagai

$$
\mathrm{Fe}^{2=} \text { (Fero) atau Fe } e^{3+} \text { (Feri) }
$$

b. Tersuspensi sebagai butiran koloid (diameter $<1 \mu \mathrm{m}$ ) atau lebih besar, seperti

$$
\mathrm{Fe}_{2} \mathrm{O}_{3}, \mathrm{FeO}, \mathrm{FeOH}, \mathrm{Fe}(\mathrm{OH})_{3} \text { dan }
$$

sebagainya.

c. Tergabung dengan zat organik atau zat padat yang inorganis (seperti tanah liat). Pada air permukaan jarang ditemukan kadar besi $(\mathrm{Fe})$ lebih besar dari $1 \mathrm{mg} / \mathrm{l}$, tetapi didalam air tanah kadar besi (Fe) dapat jauh lebih tinggi. Konsentrasi kadar besi $(\mathrm{Fe})$ yang tinggi ini dapat 
dirasakan dan dapat menodai kain, dan perkakas dapur. Pada air yang tidak mengandung oksigen $\left(\mathrm{O}_{2}\right)$ seperti seringkali air tanah, besi berada sebagai $\mathrm{Fe}^{2+}$ (ferro) yang cukup dapat terlarut, sedangkan pada air sungai yang mengalir dan terjadi aerasi, $\mathrm{Fe}^{2+}$ teroksidasi menjadi $\mathrm{Fe}^{3+}$. $\mathrm{Fe}^{3+}$ ini sulit larut pada $\mathrm{pH} 6$ sampai 8 (kelarutan hanya di bawah beberapa $\mu \mathrm{m} / 1$ ), bahkan dapat menjadi ferihidroksida $\mathrm{Fe}(\mathrm{OH})_{3}$ atau salah satu jenis oksida yang merupakan zat padat dan bisa mengendap. Demikian pula dalam air sunga, besi berada sebagai $\mathrm{Fe}^{2+}, \mathrm{Fe}^{3+}$ terlarut dan $\mathrm{Fe}^{3+}$ dalam bentuk senyawa organis berupa koloid (Alaerts 1984).

B. Komposisi Kadar Besi (Fe) Dalam Air Kadar besi $(\mathrm{Fe})$ berada dalam tanah dan batuan sebagai feroksida $\left(\mathrm{Fe}_{2} \mathrm{O}_{3}\right)$ dan ferihidroksida $\left(\mathrm{Fe}(\mathrm{OH})_{3}\right)$. Dalam air besi berbentuk Ferobikarbonat $\left(\mathrm{Fe}\left(\mathrm{HO}_{3}\right)_{2}\right)$, ferohidroksida $\left(\mathrm{Fe}(\mathrm{OH})_{2}\right)$, ferosulfat $\left(\mathrm{FeSO}_{4}\right)$ dan besi organik komplek. Air tanah mengandung besi terlarut berbentuk ferro $\left(F^{2+}\right)$. Jika air tanah dipompakan keluar dan kontak dengan udara (oksigen) maka besi $\left(\mathrm{Fe}^{2+}\right)$ akan teroksidasi menjadi ferihidroksida $\left(\mathrm{Fe}(\mathrm{OH})_{3}\right)$. Ferihidroksida dapat mengendap dan berwarna kuning kecoklatan. Hal ini dapat menodai peralatan dan cucian. Bakteri Besi (Crenothrix dan Gallionella) memanfaat kan besi fero $\left(\mathrm{Fe}^{2+}\right)$ sebagi sumber energi untuk pertumbuhannya dan mengendapkan ferrihidroksida. Pertumbuhan bakteri besi yang terlalu cepat (karena adanya besi fero) menyebabkan diameter pipa berkurang dan lama kelamaan pipa akan tersumbat.

\section{Aeras i}

Perpindahan masa zat dari phase gas ke phase cair atau sebaliknya, terjadi bila ada kontak antara permukaan cairan dengan udara. Didalam praktek pengolahan air umumnya udara dan proses perpindahan gas umumnya diberi istilah "Aerasi”. Gasgas yang menjadi perhatian dibidang pengolahan air adalah $\mathrm{O}_{2}, \mathrm{CO}_{2} \mathrm{CH} \mathrm{H}_{2} \mathrm{~S}_{4}, \mathrm{NH}_{3}$ dan $\mathrm{Cl}_{2} \quad$ Gaya penggerak perpindahan massa dari udara kedalam air atau sebaliknya, dikendalikan oleh perbedaan konsentrasi zat didalam air atau sebaliknya dikendalikan oleh perbedaan konsentrasi zat didalam larutan dan kelarutan gas pada kondisi tertentu.

1. Prinsip Pengolahan Air Secara Aerasi Aerasi adalah pengolahan air dengan cara mengontakkannya dengan udara. Aerasi secara luas telah digunakan untuk mengolah air yang mempunyai kandungan kadar besi $(\mathrm{Fe})$ terlalu tinggi (mengurangi kandungan konsentrasi zat padat terlarut). Zat-zat tersebut memberikan rasa pahit pada air, menghitamkan pemasakan beras dan memberikan noda hitam kecoklatcoklatan pada pakaian yang dicuci.

\section{Proses Aerasi}

Dalam proses aerasi adalah oksigen yang ada di udara, akan bereaksi dengan senyawa ferus dan manganous terlarut merubah mereka menjadi ferric $(\mathrm{Fe})$ dan manganic oxide hydrates yang tidak bisa larut. Setelah itu dilanjutkan dengan pengendapan (sedimentasi) atau penyaringan (filtrasi). Perlu dicatat bahwa oksidasi terhadap senyawa besi didalam air tidak selalu terjadi dalam waktu yang cepat.

Apabila air mengandung zat organik, pembentukan endapan besi melalui proses aerasi terlihat sangat tidak efektif. Untuk pengolahan air minum, kebanyakan dilakukan dengan menyebarkan air agar kontak dengan udara melalui tetesan-tetesan air yang kecil (Waterfall aerators/ aerator air terjun), atau dengan mencampur air dengan gelembung-gelembung udara (bubble aerator). Dengan kedua cara tersebut jumlah oxygen pada air bisa dinaikkan sampai $60-80 \%$ (dari jumlah oksigen yang tertinggal, yaitu air yang mengandung oksigen sampai jenuh). Pada aerator terjun (waterfall aerator) cukup besar bisa menghilangkan gasgas yang terdapat dalam air.

Penurunan carbon dioxide $\left(\mathrm{CO}_{2}\right)$ oleh waterfall aerator cukup berarti, tetapi tidak memadai apabila air yang diolah sangat corrosive. Pengolahan selanjutnya seperti pembubuhan kapur atau dengan saringan marmer atau delomite yang dibakar masih dibutuhkan. 


\section{Tujuan Aerasi}

Tujuan aerasi adalah menghilangkan rasa dan bau (yang disebabkan hidrogen sulfida dan komponen organik) dengan oksida/ valatilisasi, mengoksidasi $\mathrm{Fe}$, transfer $\mathrm{O}_{2}$ ke dalam air dan membebaskan volitali gas dari dalam air. Oksidasi $\mathrm{Fe}$ dapat berjalan dengan baik pada $\mathrm{pH}$ 7,5 - 8 dalam waktu 15 menit. Endapan besi yang terbentuk dapat dihilangkan dengan koagulan dan filtrasi. Aerasi mampu mengendapkan besi jika tidak ada zat organik jenis humik dan fulvik acid (jika ada zat tersebut akan membentuk senyawa kompleks dengan besi yang tidak dapat mengendap secara sempurna setelah aerasi, dan biasanya ikatan kompleks ini berwarna, selain itu memperlambat proses oksidasi).

\section{Aerasi Metode Jatuhan (Gravity} Aerator)

Operasi aerasi dapat dilakukan dengan berbagai metoda, prinsip yang harus diupayakan adalah penciptan luas bidang kontak sebesar mungkin persatuan volume air teraerasi, dan waktu kontak seoptimum mungkin. Teknik operasional aerasi dapat dikelompokan dalam beberapa jenis :

1. Aerasi secara mekanik dengan surface aerator.

2. Aerasi dengan udara paksaan (buble aerator)

3. Aerasi dengan metode jatuhan (gravity aerator).

Aerasi metode jatuhan dapat dilakukan dengan berbagai jenis operasi antara lain :

1. Aerasi jatuh bertingkat (Cascade Aerator).

2. Aerasi aliran dalam talang dengan pelimpah.

3. Tray aeration (susunan nampan).

4. Kombinasi jatuhan dan pengudaraan dengan berlawanan.

Operasi aerasi dengan sistem ini, dilakukan memompakan air pada ketinggian tertentu kemudian dilepaskan pada titik pancaran pada bagian atas dari alat. Suhu udara dan kecepatan angin sangat berpengaruh pada laju aerasi. Waktu kontak ditentukan dengan oleh tinggi jatuhan dan kapasitas air aliran air yang direncanakan.

Rumus umum efisiensi aerasi dengan metoda jatuhan bertingkat adalah :
$K=\frac{C e-C o}{C s-C o}$

Dimana :

$\mathrm{K}=$ Koefisien efisiensi

$\mathrm{Cs}=$ Koefisiensi jenuh oksigen terlarut pada suhu operasi $\mathrm{mg} / \mathrm{liter}$.

$\mathrm{Ce}=$ Konsentrasi oksigen setelah aerasi, mg/ liter.

$\mathrm{Co}=$ Konsentrasi oksigen pada saat awal, mg/liter.

Sebagai mana dijelaskan diatas bahwa faktor yang paling dominan berpengaruh pada aerasi jatuhan adalah :

1). Suhu, ${ }^{\circ} C$.

2). Tinggi jatuhan., dalam meter.

Pengaruh kedua faktor pada efisiensi aerasi untuk berbagai jenis dirumuskan secara empiris sebagai berikut :

1. Air tanah tak terpolusi : $\mathrm{K}=0,45$. $(1+0,026 . T) . H$

2. Air tercemar: $\mathrm{K}=0,36 .(1+0,046$. T) . $\mathrm{H}$.

3. Air limbah domestik: $\mathrm{K}=0,29$. $(1+$ 0,046 . T) . H

Dimana $T=$ Suhu Air. $\mathrm{H}=$ Tinggi Jatuhan .

Untuk waktu kontak antara air dan udara untuk garvity aerator jatuhan bebas dapat dirumuskan sebagai berikut :

$t=\sqrt{\frac{2 h}{g}}$

Dimana $t=$ adalah waktu kontak air dengan udara.

$h=$ adalah tinggi jatuhan.

$g=$ adalah gaya grafitasi.

Aerasi denganweir berganda, secara empiris dirumuskan :

$$
C n=C s-[C s-C o] x\left[1-\frac{K}{n}\right]^{n} \text {.. }
$$

Dalam formulasi $n$ adalah jumlah weir atau cascade untuk jatuhan.

\section{Khlorin}

Khlorin banyak digunakan dalam pengolahan air bersih sebagai oksidator dan desinfektan. Sebagai oksidator, chlorin digunakan untuk menghilangkan bau, rasa dan warna pada pengolahan air bersih. Serta mengoksidasi Fe (II) yang banyak terkandung dalam air tanah, menjadi Fe (III).

Yang dimaksud dengan chlorin tidak hanya $\mathrm{Cl}_{2}$ saja, akan tetapi termasuk pula asam hiphochlorite $(\mathrm{HOCl})$ dan ion hipochlorite $\left(\mathrm{OCl}^{-}\right)$. Juga beberapa jenis chloramine, seperti monochloramine $\left(\mathrm{NH}_{2} \mathrm{Cl}\right)$ dan 
dichloramine $\left(\mathrm{NaCl}_{2}\right)$ termasuk didalamnya. Chlorin dapat diperoleh dari gas $\mathrm{Cl}_{2}$ atau dari garam-garam $\mathrm{NaOCl}$ (bleach) dan $\mathrm{Ca}(\mathrm{OCl})_{2}$. Chloramine terbentuk karena adanya reaksi antara amonia $\left(\mathrm{NH}_{3}\right)$, baik anorganik amonia maupun organik amonia, didalam air dengan chlorine.

Chlorine diokosida $\left(\mathrm{ClO}_{2}\right)$ sudah digunakan dalam proses pengolahan air bersih, untuk menghilangkan rasa dan bau akibat adanya phenol. Selain menghilangkan rasa dan bau $\mathrm{ClO}_{2}$ digunakan pula untuk menghilangkan zat besi (Fe), serta sebagai desinfektan dan mencegah adanya algae.

Chlorine dioksida bereaksi dengan berbagai jenis zat organik dan anorganik, tetapi tidak membentuk THM (Trihalomethane). Selain itu $\mathrm{ClO}_{2}$ tidak bereaksi dengan amoniak.

Proses pembuatan $\mathrm{ClO}_{2}$ ada 3 cara yaitu dengan mereaksikan Natrium chlorate $\mathrm{CNaClO}_{3}$ ) dengan Sulfur dioksida $\left(\mathrm{SO}_{2}\right)$, methannol $\left(\mathrm{CH}_{3} \mathrm{OH}\right)$ serta ion colorida $\left(\mathrm{Cl}^{-}\right)$.

a. $2 \mathrm{NaClO}_{3}+\mathrm{H}_{2} \mathrm{SO}_{4}+\mathrm{SO}_{2} \longrightarrow 2 \mathrm{ClO}_{2}+$ $2 \mathrm{NaHS}_{4}$

b. $2 \mathrm{NaClO}_{3}+\mathrm{CH} \underset{3}{ } \mathrm{OH}+\mathrm{H}_{2} \mathrm{SO}_{4}$

$$
\longrightarrow 2 \mathrm{ClO}_{2}+\mathrm{HCHO}+\mathrm{Na} \mathrm{SO}_{4}+\mathrm{H}_{2} \mathrm{O}
$$

c. $\mathrm{NaClO}_{3}+\mathrm{NaCl}+\mathrm{H}_{2} \mathrm{SO}_{4} \longrightarrow \mathrm{ClO}_{2}$ $+1 / 2 \mathrm{Cl}_{2}+\mathrm{Na}_{2} \mathrm{SO}_{4}+\mathrm{H}_{2} \mathrm{O}$

Kalium Permangat $\left(\mathrm{KMnO}_{4}\right)$ merupakan oksidator kuat yang sudah sejak lama digunakan. Dalam proses pengolahan air bersih, penggunaan $\mathrm{KMnO}_{4}$ adalah sebagai oksidator untuk mengurangi kadar besi $(\mathrm{Fe})$ di dalam air, serta untuk menghilangkan rasa dan bau dari air yang diolah. Selain itu $\mathrm{KMnO}_{4}$ digunakan pula sebagai algasida.

\section{METODE}

\section{A. Rancangan Penelitian}

\section{Waktu dan Lokasi}

Pelaksanaan penelitian untuk meremoval kadar besi $(\mathrm{Fe})$ dalam air bersih secara spray aerator dengan pembubuhan kaporit dengan rincina waktu pelaksanaan terlampir.

\section{Alat dan bahan}

Alat dan bahan yang digunakan dalam perancangan alat uji aerasi secara spray aerator yang digunakan adalah :
1). Alat

a. Tangki (tandon) air berkapasitas 250 liter.

b. Pompa hisap dan tekan listrik.

c. Botol tempat sampel kapasitas 500 $\mathrm{ml}$.

d. Kayu ukur.

e. Nozel diameter 1,2 $\mathrm{mm}$ dan 1,5 mm.

2). Bahan

a. Slang hantar plastik $\varnothing 12 \mathrm{~mm}$ beserta asesoris.(fiting)

b. Pipa hisap dan asesoris PVC $\varnothing 1$ " dan $3 / 4 "$

d. Kayu (papan) dengan lebar $10 \mathrm{~cm} \mathrm{x}$ $180 \mathrm{~cm}$.

e. Plastik spanduk lebar $200 \times 200 \mathrm{~cm}$ x 3 potong.

f. Kaporit Sebanyak 5 gram dan 10 gram.

\section{B. Variabel dan Definisi Operasional Variabel}

1. Variabel Penelitian

Menurut Suryabrata (1983) menyatakan bahwa variabel diartikan sebagai segala sesuatu yang menjadi obyek pengamatan penelitian. Dalam penelitian ini sebagai variabelnya adalah :

a. Kaporit dengan dosis $5 \mathrm{mg} / \mathrm{liter}$ dan 10 $\mathrm{mg} / \mathrm{liter}$ dan diameter nozel $1,2 \mathrm{~mm}$ dan $1,5 \mathrm{~mm}$ sebagai variabel bebas.

b. Kadar besi $(\mathrm{Fe})$ sebagai variabel terikat.

2. Definisi Operasional Variabel

\section{a. Nozel}

Nozel adalah sebuah alat yang terbuat dari logam kuningan yang digunakan untuk memperkecil tekanan sehingga apabila menerima tekanan air melalui pompa tekan listrik air akan menyembur (menyemprot) ke udara berbentuk semburan kecil.

\section{b. Kaporit}

Kaporit atau Chlor yang berasal dari $\mathrm{Ca}(\mathrm{OCl})_{2}$ (kaporti) yang dimasukan ke dalam air mula - mula akan bereaksi dulu dengan unsur-unsur atau senyawa pereduksi yang biasa terkandung didalamnya seperti $\mathrm{H}_{2} \mathrm{~S}, \mathrm{Fe}, \mathrm{Mn}, \mathrm{NO}_{2}, \mathrm{NH}_{3}$, zat organik dan lain - lain. Dalam penelitian dosis yang digunakan sebanyak $5 \mathrm{mg} / \mathrm{liter}$ dan10 mg/liter. 


\section{Pengumpulan data}

\section{Pelaksanaan Penelitian}

Setelah uji kelayakan alat yang telah dilakukan dan siap untuk dioperasikan, maka pelaksanaan penelitian dimulai dengan menyeting alat kembali dengan urutan pemasangan sebagai berikut :

\section{a. Pemasangan alat}

1) Pemasangan pipa hisap diameter 1 inchi $(25 \mathrm{~mm})$ dari pompa listrik ke tanki (tandon) penampung air tanah yang akan diremoval secara spray aerator dengan pembubuhan kaporit.

2) Pemasangan 2 buah nozel masingmasing berdiameter $1,2 \mathrm{~mm}$ dan 1,5 $\mathrm{mm}$ di ujung selang pipa hantar plastik diameter $12 \mathrm{~mm}$.

3) Pemasangan bak untuk menampung jatuhan air hasil proses aerasi sebanyak dua buah berukuran 180 $\mathrm{Cm} \times 180 \mathrm{Cm}$.

4) Nozel yang telah dipasang pada ujung selang diletakan di tengah bak penampung dengan harapan semburan air dari sprayer akan merata ke seluruh permukaan bak penampung.

5) Penyambungan instalasi sprayer yang telah disiapakan point (d) ke pompa tekan.

6) Seluruh persiapan alat uji selesai maka air tanah sampel siap untuk dilakukan aerasi.

\section{b. Pengambilan Data Sampel di lapangan}

1) Pengisan tangki dengan air tanah dangkal dari kran sarana air bersih Sebanyak 240 liter yang akan digunakan sebagai air sampel.

2) Menambahkan larutan besi Chlorit $\left(\mathrm{FeCl}_{3} 6 \mathrm{H}_{2} \mathrm{O}\right)$ sebanyak 1,2 gram kedalam tangki penampung untuk dilakukan analisa tahap ke I kemudian aduk hingga benar - benar tercampur.

3) Ambil air sampel dalam tangki (tandon) yang sudah diberi penambahan besi Chlorit $\left(\mathrm{FeCl}_{3} 6 \mathrm{H}_{2} \mathrm{O}\right.$ ) namun belum dibubuhi kaporit sebanyak $500 \mathrm{ml}$ untuk pemeriksaan sampel awal.

4) Tambahkan kaporit sebanyak 5 $\mathrm{mg} /$ liter kedalam tangki air bahan sampel yang telah ditambah besi Chlorit $\left(\mathrm{FeCl}_{3} 6 \mathrm{H}_{2} \mathrm{O}\right)$ kemudian aduk hingga rata. Lakukan pengambilan air untuk sampel sebelum perlakukan aerasi (So)

sebanyak $500 \mathrm{ml}$.

5) Ukur ketinggian semburan, $\mathrm{pH}$, dan suhu air sebelum di lakukan aerasi.

6) Lakukan aerasi dengan cara sprayer ke atas dengan bantuan pompa listrik hingga membentuk semacam air mancur kemudian biarkan air menyembur selama 10 menit untuk memastikan air yang keluar adalah air yang telah tercampur larutan besi dan kaporit.

7) Setelah 10 menit ambil air hasil aerasi dan masukan kedalam botol sampel yang telah disediakan. Demikian selanjutnya hingga mencapai jumlah 10 botol dari hasil sprayer melalui nozel $1,2 \mathrm{~mm}$ sebanyak 5 sampel dan dari hasil sprayer melalui nozel $1,5 \mathrm{~mm}$ dengan dosis kaporit 5 gram/liter 5 sampel.

8) Pengambilan sampel dilakukan dengan interval waktu 10 menit antar sampel satu dengan yang lainnya.

9) Untuk perlakuan penelitian tahap ke II dengan penambahan besi Chlorit ( $\mathrm{FeCl}_{3} 6 \mathrm{H}_{2} \mathrm{O}$ ) sebanyak 2,4 gram dan kaporit dengan dosis 10 gram/liter, dengan perlakukan sama dengan perlakuan tahap ke I.

\section{Analisa Kadar Besi}

Untuk analisa besi ( $\mathrm{Fe}$ ) alat dan bahan penelitain yang digunakan dengan metoda Spektrofotometri.

a. Peralatan

1) Spectrophotometer Shimsdzu dengan panjang gelombang $510 \mu \mathrm{m}$ dengan lintasan cahaya minimum 1 $\mathrm{cm}$ atau filter fotometer yang dilengkapi suatu filter hijau yang mempunyai transmitans maksimum $510 \mu \mathrm{m}$ dengan lintasan cahaya 1 $\mathrm{cm}$.

2) otplate/ alat pemanas listrik.

3) Erlenmeyer $100 \mathrm{ml} 2$ buah.

4) Pipet $5 \mathrm{ml}, 25 \mathrm{ml}, 10 \mathrm{ml}$.

\section{b. Bahan/Reagen}

Air suling yang digunakan adalah bebas besi atau air suling ulang untuk menyiapkan larutan baku dan reagen.

1) Larutan Klorida $(\mathrm{HCl})$ pekat mengandung besi kurang dari 0,00005\%. 
2) Iarutan

Hidrokxilamine

$\left(\mathrm{NH}_{2} \mathrm{OH}, \mathrm{Cl}\right) \quad 10 \quad$ gram

Hidroxilamine Hidroxida dilarutkan dalam $100 \mathrm{ml}$ air suling bebas besi. (larutan akan stabil dalam beberapa bulan).

3) Larutan Amonium Acetate Buffer $\left(\mathrm{NH}_{4} \mathrm{C}_{2} \mathrm{H}_{3} \mathrm{O}_{2}\right) \quad$ sebanyak 250 gram amonium acetate dilarutkan dalam $150 \mathrm{ml}$ air suling bebas besi dan $700 \mathrm{ml}$ asam asetat (glasial) pekat. (larutan ini harus dibuat baru).

4) Larutan Natrium Acetate ( $\mathrm{NaC}_{2} \mathrm{H}_{2} \mathrm{O}_{2} 3 \mathrm{H}_{2} \mathrm{O}$ ) sebanyak 200 gram Natirum Acetate dilarutkan dalam $800 \mathrm{ml}$ air suling bebas besi.

5) Larutan Phenanthrolin Monohodrate $\left(\mathrm{C}_{12} \mathrm{H}_{8} \mathrm{~N}_{2} \mathrm{H}_{2} \mathrm{O}\right)$ sebanyak $100 \mathrm{mg}$ dilarutkan dalam $100 \mathrm{ml}$ air suling bebas besi dengan diaduk dan dipanaskan sampai $80^{\circ} \mathrm{C}$ (tidak sampai mendidih). Larutan dibuang bila warnanya menjadi gelap. Pemanasan tidak perlu dilakukan bila ke adaan air suling bebas besi telah ditambahkan 2 tetes asam klorida pekat. (larutan stabil dalam beberapa bulan).

\section{c. Sampel}

1) Sampel air tanah yang digunakan dalam penelitian ini menggunakan konsentrasi besi ( $\mathrm{Fe}$ ) buatan dengan menggunakan Besi Chlorite $\left(\mathrm{FeCl}_{3} 6 \mathrm{H}_{2} \mathrm{O}\right)$ sebesar 1,2 gram

dan 2,4 gram berbentuk $F e$ yang terlarut sehingga dianalogikan dengan keberadaan besi (Fe) dalam air tanah yang umumnya berbentuk $\mathrm{Fe}^{2+}$.

2) Air bahan baku sampel adalah air tanah dari sumur air tanah dangkal yang diambil dari kran laboratorium teknik UNIPA Surabaya.

\section{Pengambilan data di laboratorium}

a. Menyiapkan bahan berupa air sampel awal dan sampel hasil sprayer masingmasing $500 \mathrm{ml}$ sebanyak 23 botol. b. Pemeriksaan/ Pengujian Sampel :

Pemeriksaan besi total dan besi terlarut dengan cara :

1) Ambil 2 erlemeyer $100 \mathrm{ml}$ dan isi masing-masing erlemeyer dengan $25 \mathrm{ml}$ sampel air dan air aquades (sebagai blanko).

2) Tambahkan masing-masing $1 \mathrm{ml}$ $\mathrm{HCl}$ pekat.

3) Tambahkan 0,5 ml Hydroxylamine $\left(\mathrm{NH}_{2} \mathrm{OH} . \mathrm{HCl}\right)$

4) Panaskan hingga volume menjadi \pm $15-20 \mathrm{ml}$ (ini khusus untuk sampel saja).

5) Dinginkan dan encerkan dengan air aquades hingga mencapai $25 \mathrm{ml}$ dalam labu ukur.

6) Tambah masing - masing $5 \mathrm{ml}$ larutan Ammonium Acetate Buffer pada masing-masing erlemeyer.

7) Tambahkan masing - masing erlemeyer masing-masing $1 \mathrm{ml}$ larutan Phenanthrolin Monohydrate.

8) Baca pada spketrofotometer dengan panjang gelombang $510 \mu \mathrm{m}$ dan hitung hasil absorbansi pada rumus hasil kalibrasi atau kurva kalibrasi.

c. Pengukuran kadar besi

Ukur kadar besi (Fe) dengan menggunakan spektrofotometer. Setelah diperoleh hasil, baru dihitung efektifitasnya. Dengan rumus efektivitas pengolahan $\left(\sum p\right)$.

$\sum p \mathrm{Fe}=\frac{A-B}{A} \times 100 \%=\ldots . . . \%$.

Keterangan :

$\mathrm{A}=$ Kadar Besi (Fe) awal ; $\mathrm{B}=$ Kadar Besi (Fe) akhir ;

\section{E. Metode Analisa Data}

Di dalam mengambil kesimpulan tentang adanya pengaruh pembubuhan kaporit sebelum aerasi pada air tanah terhadap penurunan kadar besi (Fe), maka penulis menganalisis data dengan uji efektifitas dan uji ANOVA untuk memprediksi pengaruh variabel bebas terhadap variabel terikat, yaitu sebelum dan sesudah perlakuan aerasi secara spray aerator dengan pembubuhan kaporit pada air bersih menggunakan bantuan komputers Statistical Product and Service Solutions. 
HASIL

A. Hasil Penelitian

1. Hasil pemeriksaan Laboratorium kadar besi ( $\mathrm{Fe})$

TABEL 1 : Sampel Air Tanah Hasil Analisis Laboratorium

\begin{tabular}{|c|c|c|c|c|}
\hline \multirow{2}{*}{ NAMA SAMPEL } & \multicolumn{2}{|c|}{ KAPORIT 5 mg/liter } & \multicolumn{2}{|c|}{ KAPORIT 10 mg/Liter } \\
\hline & Nozel 1,2 mm & Nozel $1,5 \mathrm{~mm}$ & Nozel 1,2 mm & Nozel $1,5 \mathrm{~mm}$ \\
\hline Sampel awal (Sx) & & & & \\
\hline $\begin{array}{l}\text { So (sebelum } \\
\text { aerasi) }\end{array}$ & \multicolumn{2}{|c|}{3.019} & \multicolumn{2}{|c|}{3.494} \\
\hline Sampel 1 & 1.06 & 1.136 & 1.106 & 1.244 \\
\hline Sampel 2 & 1.259 & 1.106 & 1.075 & 1.183 \\
\hline Sampel 3 & 2.285 & 1.029 & 1.642 & 1.229 \\
\hline Sampel 4 & 1.244 & 1.091 & 1.122 & 1.244 \\
\hline Sampel 5 & 1.137 & 1.351 & 1.106 & 1.091 \\
\hline JUMLAH & 6.985 & 5.713 & 6.051 & 5.991 \\
\hline RATA-RATA & 1.397 & 1.1426 & 1.2102 & 1.1982 \\
\hline
\end{tabular}

\section{B. Analisa Data}

1. Analisa Efisiensi

Untuk mengetahui penurunan kadar besi (Fe) yang terkandung dalam sampel air bersih dengan pembubuhan kaporit sebelum dan sesudah dilakukan aerasi secara spray aerator, maka dilakukan analisis efisiensi dari masing-masing perlakuan sebagai berikut :

\section{a). Data Awal}

Data awal merupakan keadaan sampel air bersih yang tidak mendapat perlakuan aerasi setelah penambahan besi chlorite $\left(\mathrm{FeCl}_{3} 6 \mathrm{H}_{2} \mathrm{O}\right) \quad$ sebanyak 0,5 $\mathrm{mg} / \mathrm{liter} 4,045 \mathrm{mg} / \mathrm{liter}$.

b). Data Kadar besi (Fe) Air bersih Sebelum Aerasi.

1). Sampel air besih tahap pertama setelah penambahan besi chlorite $\quad\left(\mathrm{FeCl}_{3} 6 \mathrm{H}_{2} \mathrm{O}\right)$ sebanyak $0,5 \mathrm{mg} / \mathrm{liter}$ dan kaporit $5 \mathrm{mg} /$ liter 3,0190 mg/liter.

2). Sampel air besih tahap kedua setelah penambahan besi chlorite $\quad\left(\mathrm{FeCl}_{3} 6 \mathrm{H}_{2} \mathrm{O}\right)$ sebanyak 05 , $\mathrm{mg} / \mathrm{liter}$ dan kaporit $10 \mathrm{mg} / \mathrm{liter} 3,494 \mathrm{mg} / \mathrm{liter}$.

\section{c). Nilai efisiensi Variasi}

Berdasarkan nilai perlakuan dari masing-masing variasi maka nilai efisiensi variasi dosis kaporit dan diameter nozel untuk:

1). Variasi tahap pertama : a. Nozel diameter 1,2 $\mathrm{mm}$ dengan dosis kaporit 5 $\mathrm{mg} /$ liter.

$$
\begin{gathered}
\sum \rho F e=\frac{3,019-1,397}{3,019} \times 100 \%=53,726 \% . \\
\text { b. } \begin{array}{l}
\text { Nozel biameter } 1,5 \mathrm{~mm} \\
\text { dengan dosis kaporit } 5 \\
\text { mg/liter. }
\end{array}
\end{gathered}
$$

$$
\begin{gathered}
\sum \rho F e=\frac{3,019-1,1426}{3,019} \times 100 \%=61,153 \% . \\
\text { 2). Variasi tahap kedua : } \\
\text { a. } \begin{array}{l}
\text { Nozel diameter } 1,2 \mathrm{~mm} \\
\text { dengan dosis kaporit } 10 \\
\text { mg/liter. }
\end{array}
\end{gathered}
$$
a. Nozel diameter $1,2 \mathrm{~mm}$ dengan dosis kaporit 10 $\mathrm{mg} / \mathrm{liter}$.

$$
\begin{gathered}
\sum \rho F e=\frac{3,494-1,210}{3,494} \times 100 \%=65,36 \% . \\
\text { b. } \begin{array}{l}
\text { Nozel diameter } 1,5 \mathrm{~mm} \\
\text { dengan dosis kaporit } 10 \\
\text { mg/liter. }
\end{array} \\
\sum \rho F e=\frac{3,494-1,198}{3,494} \times 100 \%=65,71 \% .
\end{gathered}
$$

\section{Analisa Anova Dua Arah (two factorial design).}

untuk membuktikan adanya pengaruh variasi kaporit dan diameter nozel terhadap removal kadar besi (Fe) pada air bersih baik sebelum maupun sesudah perlakuan dengan spray 
aerator, maka dilakukan Uji Analisis Variansi yang pada dasarnya adalah menghitung $(F)$ score bertujuan untuk mengetahui :

1). Apakah diameter nozel mempengaruhi removal kadar besi (Fe) dalam air bersih.

2). Berapa besar pengaruh kaporit dalam Removal kadar besi (Fe) dalam air bersih secara Spray Aerator.

3). Seberapa besar pengaruh nozel dan kaporit secara bersama-sama untuk meremoval kadar besi (Fe) dalam air bersih secara Spray Aerator.

\section{c. Univariate Analysis of Variance}

\section{TABEL 2 : Between-Subjects Factors}

\begin{tabular}{|c|c|c|}
\hline \multirow{8}{*}{$\begin{array}{l}\text { Nozel dan } \\
\text { Dosis } \\
\text { kaporit }\end{array}$} & & $\mathrm{N}$ \\
\hline & 1. Sampel awal (air bersih + besi & \\
\hline & chlorite) tanpa erasi. & 2 \\
\hline & 2. Sampel mula-mula (besi & \\
\hline & $\begin{array}{l}\text { chlorite + kaporit } 5 \mathrm{mg} / \mathrm{l} \text { dan } \\
10 \mathrm{mg} / \mathrm{l} \text { ) tanpa dilakukan } \\
\text { aerasi. }\end{array}$ & 2 \\
\hline & $\begin{array}{l}\text { 3. Aerasi dengan nozel } 1,2 \mathrm{~mm} \\
\text { dan nozel } 1,5 \mathrm{~mm} \text { kaporit } 5\end{array}$ & 10 \\
\hline & $\begin{array}{l}\mathrm{mg} / \text { /liter (tahap I). } \\
\text { 4. Aerasi dengan nozel } 1,2 \mathrm{~mm}\end{array}$ & \\
\hline & $\begin{array}{l}\text { dan nozel 1,5 mm kaporit } 10 \\
\mathrm{mg} / \text { /iter (tahap II). }\end{array}$ & 10 \\
\hline Variasi & 1. Dosis kaporit $5 \mathrm{mg} / \mathrm{liter}$. (tahap & 12 \\
\hline Kaporit 5 & & 12 \\
\hline $\begin{array}{l}\mathrm{mm} \text { dan } 10 \\
\mathrm{~mm}\end{array}$ & $\begin{array}{l}\text { 2. Dosis kaporit } 10 \mathrm{mg} / \mathrm{liter} \\
\text { (tahap II) }\end{array}$ & 12 \\
\hline
\end{tabular}

\section{d. Descriptive Statistic}

TABEL 3 : Descriptive Statistics

\begin{tabular}{|c|c|c|c|c|}
\hline $\begin{array}{c}\text { Nozel dan Dosis } \\
\text { kaporit }\end{array}$ & $\begin{array}{l}\text { Variasi Kaporit } 5 \\
\text { mm dan } 10 \mathrm{~mm}\end{array}$ & Mean & Std. Deviation & $\mathbf{N}$ \\
\hline $\begin{array}{l}1(\mathrm{Sx}) \\
\text { sampel }\end{array}$ & $\begin{array}{l}1 \text { Sampel mula- } \\
\text { mula (tahap I) }\end{array}$ & 4.405000E0 & . & 1 \\
\hline & $\begin{array}{l}2 \text { Sampel mula- } \\
\text { mula (tahap II) }\end{array}$ & 4.405000E0 & . & 1 \\
\hline 2 (So) & $\begin{array}{l}\text { Total } \\
1 \text { Sampel awal }\end{array}$ & 4.405000E0 & .0000000 & 2 \\
\hline sampel awal & tahap (tahap I). & 3.019000E0 & . & 1 \\
\hline & $\begin{array}{l}2 \text { Sampel awal } \\
\text { (tahap II). }\end{array}$ & 3.494000E0 & . & 1 \\
\hline 3 (S1) tahap I & $\begin{array}{l}\text { Total } \\
1 \text { Nozel diameter }\end{array}$ & $3.256500 \mathrm{E} 0$ & .3358757 & 2 \\
\hline Kaporit $5 \mathrm{mg} / \mathrm{liter}$ & $1,2 \mathrm{~mm}$ & 1.397000E0 & .5030323 & 5 \\
\hline & $\begin{array}{l}2 \text { Nozel diameter } \\
1,5 \mathrm{~mm}\end{array}$ & 1.210200E0 & .2419839 & 5 \\
\hline 4 (S1) Tahap II & $\begin{array}{l}\text { Total } \\
1 \text { Nozel diameter }\end{array}$ & 1.303600E0 & .3849425 & 10 \\
\hline $\begin{array}{l}\text { Kaporit } 10 \mathrm{mg} / \mathrm{liter} \\
\text { (setelah di aerasi) }\end{array}$ & $1,2 \mathrm{~mm}$ & 1.142600E0 & .1228629 & 5 \\
\hline & $\begin{array}{l}2 \text { Nozel diameter } \\
1,5 \mathrm{~mm} \text {. }\end{array}$ & 1.198200E0 & .0649361 & 5 \\
\hline Total & $\begin{array}{l}\text { Total } \\
1 \text { Variasi tahap I. } \\
2 \text { variasi tahap II. } \\
\text { Total }\end{array}$ & $\begin{array}{l}1.170400 \mathrm{E} 0 \\
1.676833 \mathrm{E} 0 \\
1.661750 \mathrm{E} 0 \\
1.669292 \mathrm{E} 0 \\
\end{array}$ & $\begin{array}{l}.0971690 \\
1.0503424 \\
1.0965869 \\
1.0501410 \\
\end{array}$ & $\begin{array}{l}10 \\
12 \\
12 \\
24\end{array}$ \\
\hline
\end{tabular}

Tabel : merupakan ringkasan statistik deskriptif dari data yang dianalisis, berupa mean (rata - rata) dan standar deviasi. Dari tabel : 4.4 mean (rata - rata) kadar besi ( $\mathrm{Fe})$ air bersih yang termasuk dalam kaporit 5 $\mathrm{mg} /$ liter dengan menggunakan nozel diameter 1,2 mm adalah 1,397 sedangkan standar deviasinya 0,5030 dengan jumlah sampel 5 sampel. Mean yang termasuk dalam kaporit $10 \mathrm{mg} /$ liter dengan nozel 1,2 $\mathrm{mm}$ adalah 1,1426 dengan standar deviasi 0,1228 jumlah 5 sampel.

Mean (rata - rata) yang termasuk dalam kaporit $5 \mathrm{mg} /$ liter dengan nozel $1,5 \mathrm{~mm}$ adalah 1,2102 dengan standar deviasi 0,2419 jumlah 5 sampel. Untuk men (rata - 
rata) untuk kaporit $10 \mathrm{mg} /$ liter dengan nozel $1,5 \mathrm{~mm}$ adalah 1,1982 dengan standar deviasi 0,0649 jumlah sampel 5 sampel.

Adapun mean keseluruhan pada aerasi tahap pertama, dosis kaporit $5 \mathrm{mg} / \mathrm{liter}$ diameter nozel 1,2 $\mathrm{mm}$ dan nozel diameter $1,5 \mathrm{~mm}$ adalah 1,6768 standar deviasi 1,0503 jumlah 12 sampel, dan mean (ratarata) aerasi tahap kedua kaporit $10 \mathrm{mg} / \mathrm{liter}$ nozel $1,2 \mathrm{~mm}$ dan $1,5 \mathrm{~mm}$ adalah

1.6617 standar deviasi 1.0965 jumlah 12 sampel. Dari keseluruhan sampel (subeyek) yang ada (24 sampel) diperoleh mean 1,6692 standar deviasi 1,0501.

\section{e. Levene's Test of Equality of Error Variances $^{a}$}

\section{TABEL 4 : Levene's Test of Equality of Error Variances $^{\mathrm{a}}$}

Dependent Variable:Hasil aerasi

\begin{tabular}{cccc}
\hline $\mathbf{F}$ & $\mathbf{d f 1}$ & $\mathbf{d f 2}$ & Sig. \\
1.714 & 7 & 16 & .176
\end{tabular}

Tests the null hypothesis that the error variance of the dependent variable is equal across groups. a. Design: Intercept + Nozel + Variasi + Nozel * Variasi

Uji Leven's pada tabel : 4.5 untuk menguji hipotesis nihil yang menyatakan bahwa masing - masing varian dari variabel terikat (dependent) adalah sama (homogen). Dengan demikian perlu dirumuskan hipotesis yang akan diuji yaitu :

Ho = varian variabel terikat adalah sama (homogen).

$\mathrm{Ha}=$ varian variabel terikat adalah tidak sama (heterogen).

Pengambilan keputusan didasarkan pada hasil probablitas (sig.) yang diperoleh yaitu :

1. Jika probablitas $>0,05$ maka hipotesis nihil diterima.

2. Jika probabilitas $<0,05$ maka hipotesis nihil ditolak.

Dari tabel :4.5 tes hitung sebesar 1,714 dengan nilai probabilitas ( signifikansi ) 0,176 . Oleh karena angka probabilitas (sig.) lebih besar dari 0,05 maka hipotesis nihil diterima dan hipotesis alternatif ditolak, yang berarti bahwa varian variabel terikat adalah sama ( homogen ), sehingga memenuhi persyaratan untuk di analisis varian.

\section{f. Tests of Between-Subjects Effects}

TABEL 5 : Tests of Between-Subjects Effects

Dependent Variable:Hasil aerasi

\begin{tabular}{|c|c|c|c|c|c|}
\hline $\begin{array}{c}\text { Source } \\
\text { (1) }\end{array}$ & $\begin{array}{l}\text { Type III Sum } \\
\text { of Squares } \\
(2)\end{array}$ & $\begin{array}{l}\text { Df } \\
(3)\end{array}$ & $\begin{array}{c}\text { Mean Square } \\
\text { (4) }\end{array}$ & $\begin{array}{c}\text { F (hitung) } \\
(5)\end{array}$ & $\begin{array}{l}\text { Sig. } \\
(6)\end{array}$ \\
\hline $\begin{array}{l}\text { Corrected } \\
\text { Model }\end{array}$ & $24.041^{\mathrm{a}}$ & 7 & 3.434 & 41.514 & .000 \\
\hline Intercept & 85.607 & 1 & 85.607 & $1.035 \mathrm{E} 3$ & .000 \\
\hline Variasi Nozel & 23.833 & 3 & 7.944 & 96.030 & .000 \\
\hline Variasi kaporit & .025 & 1 & .025 & .298 & .593 \\
\hline $\begin{array}{l}\text { Variasi Nozel * } \\
\text { Variasi kaporit }\end{array}$ & .206 & 3 & .069 & .832 & .496 \\
\hline Error & 1.324 & 16 & .083 & & \\
\hline Total & 92.241 & 24 & & & \\
\hline Corrected Total & 25.364 & 23 & & & \\
\hline
\end{tabular}

a. $\quad$ R Squared $=.948$ (Adjusted R Squared $=.925)$

Test between - subyects effects tabel :4.6 dilakukan untuk menguji pengaruh (efek) yang ditimbulkan masing - masing sampel. Kolom (1) faktor yang akan diuji, kolom (2) Jumlah kuadrat (JK) dari faktor yang dianalisis, kolom (3) derajat kebebasan (df), kolom (4) rata - rata kuadrat (RK) faktor yang dianalisis, kolom (5) menunjukkan $F_{\text {ratio }}$ dan kolom (6) signifikansi (sig.). Dari tabel :4.6 diperoleh jumlah kuadrat variabel $\left(R K_{B}\right) 23,517$ jumlah kuadrat faktor Media $\left(R K_{-A}\right) 7,839$ dan jumlah kuadrat variabel kadar besi (Fe) sampel dan media $\left(R K_{A B}\right) 0,594$.

$F_{\text {ratio (F hitung) }}$ pada tabel :4.6 untuk variasi diameter nozel 96,030. Apabila dikonfirmasikan dengan $F_{\text {tabel }}$ dengan taraf 
siginifikansi $0,05(5 \%)$, dimana (dk) nya 2 untuk pembilang dan 16 untuk penyebut, diperoleh angka 3,40 dan taraf signifikansi $0,01(1 \%)=5,61$ maka $F_{\text {tabel }}$ lebih kecil dari $F_{\text {ratio }}$ maka hipotesis alternatif $(\mathrm{Ha})$ hipotesis nihil (Ho) "ditolak". Yang berarti variasi diameter nozel dan dosis kaporit mempengaruhi proses removal kadar besi (Fe) dalam air bersih secara Spray Aerator. Dalam hal ini kemungkinan yang terjadi :

a). Variasi sprayer nozel $1,2 \mathrm{~mm}$ dosis kaporit $5 \mathrm{mg} / \mathrm{liter}$ dan variasi sprayer nozel $1,5 \mathrm{~mm}$ dosis kaporit $10 \mathrm{mg} / \mathrm{liter}$ sama-sama mempengaruhi.

b). Variasi sprayer nozel $1,2 \mathrm{~mm}$ dosis kaporit $5 \mathrm{mg} /$ liter tidak berpengaruh terhadap proses removal kadar besi $(\mathrm{Fe})$ secara Spray Aerator.

c). Variasi sparayer nozel 1,2 $\mathrm{mm}$ dengan dosis kaporit $5 \mathrm{mg} / \mathrm{liter}$ berpengaruh terhadap proses removal kadar besi $(\mathrm{Fe})$ secara Spray Aerator.

Untuk mengetahui kemungkinan tersebut dilakukan perhitungan pasca Anova. Dari tabel :4.6 diperoleh $F_{\text {ratio }}$ untuk faktor media ( variasi aerasi diameter nozel dan dosis kaporit) sebesar 0,298 . Bila nilai $F_{\text {ratio }}$ dikomfirmasikan dengan $F_{\text {tabel }}$ dengan alfa $=0,05$ atau taraf signifikansi $5 \%$, dimana (dk) nya 1 untuk pembilang, 16 untuk penyebut diperoleh angka 4,49 yang lebih kecil dari nilai $F_{\text {ratio }}$ berarti hipotesis alternatif (Ha) diterima untuk taraf signifikansi $5 \%$. Sementara untuk alfa $=0,01$ atau taraf signifikansi $1 \%=8,53$ lebih besar dari $F_{\text {ratio }}$ maka hipotesis alternatif $(\mathrm{Ha})$ ditolak dan hipotesis nihil (Ho) di terima.

Berdasarkan hasil analisis variasi aerasi (diameter nozel dan dosis kaporit) mempengaruhi terhadap proses removal kadar besi $(\mathrm{Fe})$ dalam air bersih secara Spray Aerator. Dalam hal ini ada dua kemungkinan yang terjadi yaitu variasi tahap pertama dan tahap kedua sama-sama mempengaruhi proses removal kadar besi (Fe) dalam air bersih secara Spray Aerator. Variasi aerasi pertama mempengaruhi proses removal kadar besi (Fe) variasi ke dua tidak, atau sebaliknya. Untuk mengetahui kemungkinan tersebut dilakukan perhitungan. Bila menggunakan alfa 0,05 yang diterima $\mathrm{Ha}$, jadi perlu uji Anova. Tapi bila menggunakan alfa 0,01 tidak perlu karena yang diterima adalah $\mathrm{Ho}$.

Sementara pengaruh variasi aerasi secara bersama-sama terhadap hasil aerasi diperoleh angka 0,832 bila dikomfirmasikan dengan $F_{\text {tabel }}$ dengan (df) nya 2 pembilang dan 16 penyebut, (sig.0,05) diperoleh angka 3,63 dan $($ sig. 0,01$)=6,23$, maka terlihat $F_{\text {ratio }}$ jauh lebih kecil $F_{\text {tabel }}$. Berarti hipotesis alternatif $(\mathrm{Ha})$ ditolak, dan hipotesis nihil $(\mathrm{Ho})$ diterima.

\section{g. Post Hoc tests}

Analisa Post Hoc tests dilakukan untuk mengetahui variasi sprayer aerator, mana yang berbeda dan mana yang tidak. Hal ini dapat dilakukan bila $F$ hitungnya menunjukan ada perbedaan.

\section{Nozel dan Dosis kaporit}

TABEL 6 : Post Hoc Test Variasi Sprayer Aerator Multiple Comparisons Multiple Comparisons

\begin{tabular}{|c|c|c|c|c|c|c|c|}
\hline & $\begin{array}{c}\text { (I) } \\
\text { Nozel dan } \\
\text { Dosis } \\
\text { kaporit }\end{array}$ & $\begin{array}{c}\text { (J) } \\
\text { Nozel dan } \\
\text { Dosis } \\
\text { kaporit }\end{array}$ & $\begin{array}{c}\text { Mean } \\
\text { Difference (I- } \\
\text { J) }\end{array}$ & Std. Error & Sig. & $\begin{array}{c}95 \% \\
\text { Confidence } \\
\text { Interval }\end{array}$ & \\
\hline & & & & & & Lower Bound & $\begin{array}{l}\text { Upper } \\
\text { Bound }\end{array}$ \\
\hline \multirow[t]{5}{*}{$\begin{array}{l}\text { Tukey } \\
\text { HSD }\end{array}$} & $\begin{array}{c}1 \\
\text { mula-mula }\end{array}$ & $\begin{array}{l}2 \text { Tanpa } \\
\text { aerasi }\end{array}$ & $1.148500^{*}$ & .2876238 & .005 & .325603 & 1.971397 \\
\hline & & $\begin{array}{l}3 \text { Sebelum } \\
\text { Aerasi }\end{array}$ & $3.101400^{*}$ & .2227924 & .000 & 2.463987 & 3.738813 \\
\hline & & $\begin{array}{l}4 \text { Nozel } 1,5 \\
\mathrm{~mm}\end{array}$ & $3.234600^{*}$ & .2227924 & .000 & 2.597187 & 3.872013 \\
\hline & $\begin{array}{c}2 \\
\text { sebelum }\end{array}$ & $\begin{array}{l}1 \text { Tanpa } \\
\text { nozel }\end{array}$ & $-1.148500^{*}$ & .2876238 & .005 & -1.971397 & -.325603 \\
\hline & & $\begin{array}{l}3 \text { Nozel } 1,2 \\
\mathrm{~mm}\end{array}$ & $1.952900^{*}$ & .2227924 & .000 & 1.315487 & 2.590313 \\
\hline
\end{tabular}




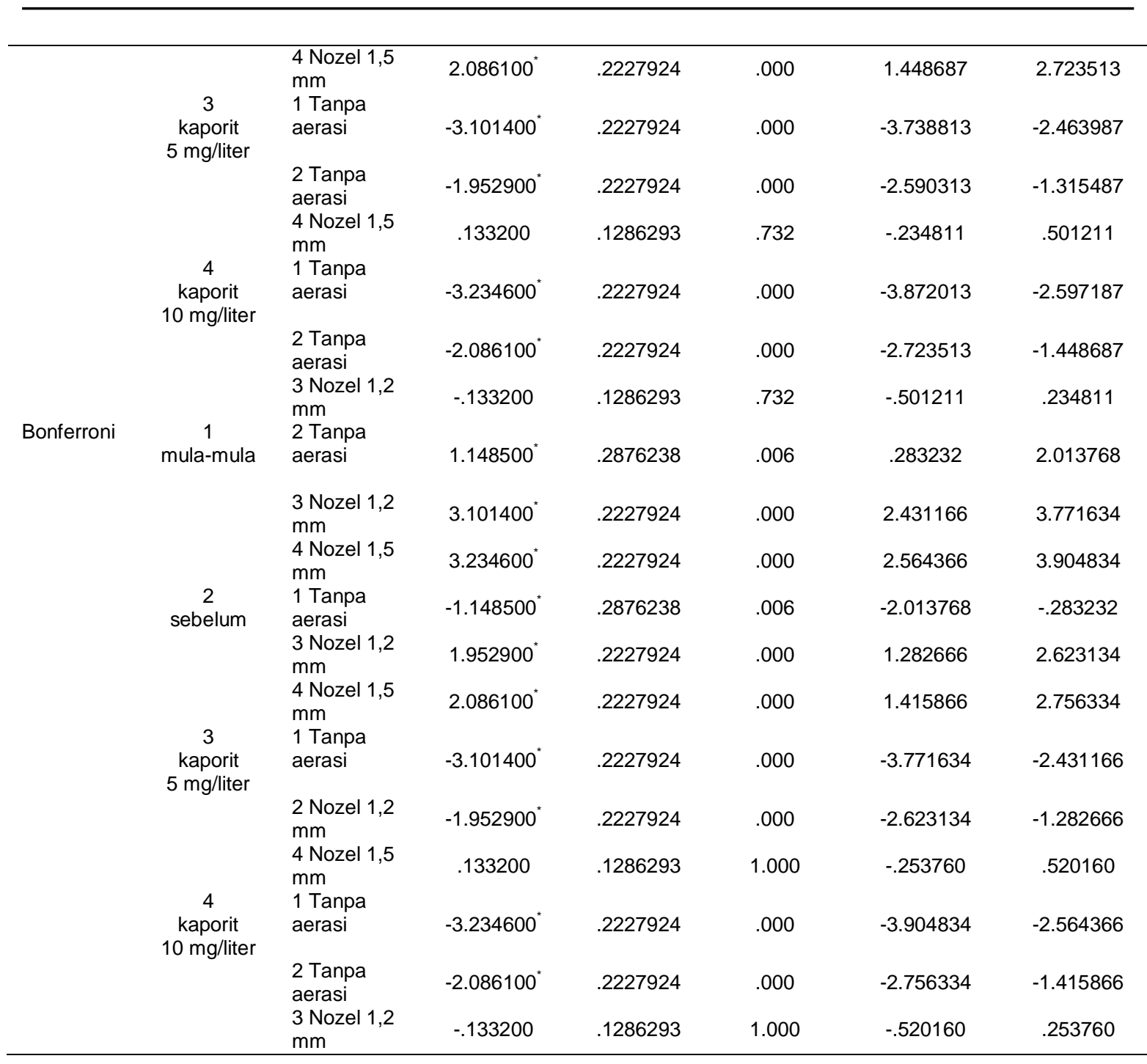

Based on observed means.

The error term is Mean Square(Error) $=.083$.

${ }^{*}$. The mean difference is significant at the .05 level.

\section{h. Homogeneous Subsets}

Homogeneous Subsets mencari untuk menguji variasi media sprayer mana yang tidak berbeda atau tidak memiliki perbedaan yang signifikan dengan variasi lainnya. Berdasarkan tabel : 4.8 terlihat subset 1 terdapat variasi tahap pertama nozel $1,5 \mathrm{~mm}$ (dosis kaporit $5 \mathrm{mg} / \mathrm{liter}$ dan $10 \mathrm{mg} / \mathrm{liter}$ ) dengan angka 1,1704 dan variasi tahap ke dua (Nozel 1,2 mm dosis kaporit $5 \mathrm{mg} / \mathrm{tr}$ dan $10 \mathrm{mg} / \mathrm{ltr}$ ) dengan angka 1,3036. Berarti variasi pertama dan variasi kedua ada perbedaan secara signifikan yaitu 0,931 yang bila dibandingkan dengan sampel awal 1,000 dan variasi mula-mula 1,000.

\section{TABEL 7 : Hasil Aerasi}

\begin{tabular}{lllcll}
\hline & $\begin{array}{c}\text { Nozel dan } \\
\text { Dosis kaporit }\end{array}$ & $\mathbf{N}$ & $\begin{array}{c}\text { Subset } \\
\mathbf{1}\end{array}$ & $\mathbf{2}$ & $\mathbf{3}$ \\
\hline Tukey HSD & $\begin{array}{l}\text { 4 Nozel 1,5 } \\
\text { mm Kaporit } \\
10 \mathrm{mg} / \text { liter. } \\
3 \text { Nozel 1,2 }\end{array}$ & 10 & $1.170400 \mathrm{E} 0$ & & \\
$\mathrm{~mm}$ Kaporit & 10 & $1.303600 \mathrm{E} 0$ & & \\
$10 \mathrm{mg} /$ liter & & & & \\
\hline
\end{tabular}




\begin{tabular}{|c|c|c|c|c|}
\hline \multicolumn{5}{|l|}{ Tanpa aerasi } \\
\hline $\begin{array}{l}5 \mathrm{mg} \text { dan } 10 \\
\mathrm{mg} / \text { /iter }\end{array}$ & 2 & & 256500 & \\
\hline $\begin{array}{l}\text { bersih + besi } \\
\text { chlorite (mula- } \\
\text { mula). }\end{array}$ & 2 & & & 405000E0 \\
\hline Sig. & & .931 & 1.000 & 1.000 \\
\hline
\end{tabular}

Means for groups in homogeneous subsets are displayed.

Based on observed means.

The error term is Mean Square(Error) $=.083$.

a. Uses Harmonic Mean Sample Size $=3.333$.

\section{g. Estimated Marginal Means}

TABEL 8 : Nozel dan Dosis kaporit * Variasi Kaporit 5 mm dan 10 mm

Dependent Variable:Hasil aerasi

\begin{tabular}{clccc}
\hline $\begin{array}{c}\text { Nozel dan } \\
\text { Dosis kaporit }\end{array}$ & $\begin{array}{c}\text { Variasi Kaporit 5 } \\
\mathbf{m m} \text { dan 10 mm }\end{array}$ & Mean & Std. Error & \multicolumn{2}{c}{ 95\% Confidence Interval } \\
Upper Bound
\end{tabular}

\section{Pembahasan}

Berdasarkan hasil pemeriksaan dilihat dari tabel : 4.1 menunjukan rata-rata 1,387 $\mathrm{mg} /$ liter untuk nozel diameter $1,2 \mathrm{~mm}$, dengan dosis kaporit $5 \mathrm{mg} / \mathrm{liter}$ dengan ketinggian semburan 1,40 meter, dan ratarata $1,1426 \mathrm{mg} / \mathrm{lt}$ untuk nozel $\varnothing 1,5 \mathrm{~mm}$ dengan ketinggian 3,20 meter. Maka dari kedua diameter nozel diketahui adanya perbedaan. Penurunan kadar besi $(\mathrm{Fe})$ dalam air tanah hal ini disebabkan karena adanya perbedaan tinggi semburan dan bentuk jatuhan air hasil sprayer, yaitu pada nozel $\varnothing 1,2 \mathrm{~mm}$ semburan air yang keluar berbentuk butiran kasar tidak menyebar sehingga kontak air dengan udara tidak terlalu lama. Sedangkan pada nozel $\varnothing 1,5$ $\mathrm{mm}$ semburan yang kelur lebih halus dengan penyebaran ke segala arah sehingga waktu kontak dengan udara lebih lama.
1. Beradasarkan hasil perhitungan efisiensi variasi tahap pertama dengan nozel 1,2 $\mathrm{mm}$ dengan kaporit $5 \mathrm{mg} / \mathrm{liter}$ adalah $54,05 \%$ sedangkan nozel $1,5 \mathrm{~mm}$ kaporit $5 \mathrm{mg} / \mathrm{liter} 62,15 \%$, dan variasi erasi tahap kedua menggunakan nozel $1,2 \mathrm{~mm}$ dengan dosis $10 \mathrm{mg} / \mathrm{liter}$ sebesar $64,34 \%$. Untuk Nozel $1,5 \mathrm{~mm}$ dengan kaporit $10 \mathrm{mg} /$ liter $64,69 \%$, ini berarti bahwa proses aerasi secara Spray Aerator, akan lebih efektif menggunakan variasi tahap kedua. Dalam meremoval kandungan besi $(\mathrm{Fe})$ air dalam bersih. Hal ini bisa terjadi karena aerasi pada variasi kedua memenuhi semua persyaratan proses yang diperlukan antara lain kontak antara air dan udara untuk peningkatan kadar oksigen dalam air cukup lama, bidang kontak lebih luas karena bentuk 
hasil sprayer berupa butiran air yang lebih halus dan menyebar.

2. Berdasarkan hasil penelitian di lapangan proses aerasi sangat dipengaruhi oleh :

a). Kekuatan angin yang bertiup akan mempengaruhi kesetabilan semburan air yang keluar dari masing-maing nozel.

b). Bentuk semburan yang terjadi dimana semakin tinggi semburan maka aerasi akan makin sempurna, hal ini dikarenakan waktu kontak dengan udara akan lebih lama terjadi.

c). Halus dan bentuknya semburan yang merupakan keluaran dari nozel tidak terlalu berpengaruh pada hasil aerasi apabila waktu kontak dengan udara tidak terlalu.

d). Air tanah yang diambil pada waktu musim hujan akan berbeda dengan air tanah pada musim hujan sehingga mempengaruhi besarnya kadar besi (Fe) dalam air dikarenakan air hujan dimungkinkan telah mengencerkan kadar besi yang ada dalam tanah.

3. Diameter nozel yang paling efektif untuk meremoval kadar besi $(\mathrm{Fe})$ dalam air bersih secara spray aerator dengan pembubuhan kaporit adalah nozel diameter $1,5 \mathrm{~mm}$ dengan dosis kaporit $10 \mathrm{mg} / \mathrm{liter}$. Hal ini dikarenakan bentuk semburan air yang keluar dari nozel 1,5 $\mathrm{mm}$ berbentuk butiran air yang halus sehingga kontak dengan air lebih lama.

4. Adanya perbedaan penurunan kadar besi $(\mathrm{Fe})$ dalam air bersih yang signifikan antara nozel diameter $1,5 \mathrm{~mm}$ dengan dosis kaporit $10 \mathrm{mg} / \mathrm{liter}$.

\section{KESIMPULAN DAN SARAN}

\section{A. Kesimpulan}

Dari hasil penelitian yang telah penulis laksanakan terhadap air bersih yang diambil dari kran sarana air bersih Kampus UNIPA Surabaya, maka dapat penulis simpulkan bahwa :

1. Kadar besi (Fe) air bersih sebelum dilakukan removal secara spray aerator mula - mula 4,045 mg/liter, dan untuk sampel tahap pertama dengan pembubuhan kaporit $5 \mathrm{mg} / \mathrm{liter}$, menunjukan angka 3,190 $\mathrm{mg} / \mathrm{liter}$ Sedangkan setelah dilakukan aerasi secara spray aerator melalui nozel $\varnothing 1,2$ $\mathrm{mm}$ mampu meremoval kadar besi ( $\mathrm{Fe}$ ) dalam air rata-rata 1,3970 mg/liter, dan melalui nozel $\varnothing 1,5 \mathrm{~mm}$ rata-rata 1,1426 $\mathrm{mg} /$ liter. Untuk removal kadar besi $(\mathrm{Fe})$ tahap ke dua dengan nozel $1,2 \mathrm{~mm}$ kaporit $10 \mathrm{mg} /$ liter rata-rata 1,210 $\mathrm{mg} /$ liter, dengan nozel $1,5 \mathrm{~mm}$ rata rata $1,1982 \mathrm{mg} / \mathrm{liter}$.

2. Adanya perbedaan penurunan kadar besi (Fe) air bersih yang signifikan setelah dilakukan aerasi secara spary aerator tahap pertama dan kedua Yaitu :

a). Kadar besi (Fe) air bersih sebelum dilakukan perlakuan sebesar 4,045 $\mathrm{mg} / \mathrm{liter}$.

b). Kadar besi $(\mathrm{Fe})$ air bersih tahap pertama dengan pembubuhan kaporit $5 \mathrm{mg} / \mathrm{liter}$ sebelum diaerasi sebesar 3,0190 $\mathrm{mg} / \mathrm{liter}$, setelah dilakukan aerasi menggunakan nozel diameter $1,2 \mathrm{~mm}$ rata - rata $1,3970 \mathrm{mg} / \mathrm{liter}$ dan diameter nozel $1,5 \mathrm{~mm}$ rata-rata $1,1426 \mathrm{mg} /$ liter.

c). Kadar besi $(\mathrm{Fe})$ air bersih tahap kedua setelah pembubuhan kaporit $10 \mathrm{mg} /$ liter sebelum diaerasi sebesar 3,494 $\mathrm{mg} / \mathrm{liter}$, setelah dilakukan aerasi menggunakan nozel diameter $1,2 \mathrm{~mm}$ rata-rata $1,2102 \mathrm{mg} /$ liter, dan nozel diameter $1,5 \mathrm{~mm}$ rata rata $1,1982 \mathrm{mg} /$ liter.

\section{B. Saran}

1. Agar air tanah dengan kandungan besi (Fe) cukup tinggi dapat diturunkan sehingga memenuhi syarat sebagai air bersih, maka cara spray aerator dapat digunakan sebagai salah satu alat alternatif yang dapat digunakan.

2. Membuat bak untuk menampung hasil aerasi kemudian diendapkan selama satu hari setelah itu baru dapat dipergunakan sebagai air bersih.

3. Perlu kontrol kualitas air dengan para meter lain seperti kandungan Mangan (Mn) karena keberadaannya di dalam air bisa selalu ada dengan besi ( $\mathrm{Fe})$.

4. Oksidasi besi dengan aerasi secara spray aerator akan memberikan prospek bagus yaitu dapat digunakan sebagai awal (pretereatmaent) terhadap air tanah yang mengandung kadar besi cukup tinggi dan sulit teroksidasi dengan pengolahan biasa.

5. Perlu penelitian lebih lanjut dengan nozel dan ketinggian semburan serta dosis kaporit yang lebih bervariasi. 


\section{DAFTAR PUSTAKA}

Alaerts,G dan Sumestri,S, 1984, Metode Penelitian Air, Penerbit Usaha Nasional Surabaya.

Azrul Azwar,1983 Pengantar IImu Kesehatan Lingkungan,cetakan ketiga, Penerbit Mutiara Jakarata.

Andayani,W dan Lindu M, Desinfeksi Air,Majalah Air Minum, N0.83/tahun XXJanuari 1999, Jakarta.

Anonim, 2002, Draft Peraturan Teknik "Proses desinfeksi"Perpamsi Jakarta.

Anonim 1992, Chlor atau Kaporit Untuk Air Minum, PT. Inti Kaliasin.

Anton Dajan, 1983, Pengantar Metode Statistik, LP3ES.

Carlson, R.M and IL Caple. 1987 Organochemical Implications of Water Chlorination, Pp 6 :-75 in ILL Jollry, ed Water Chlorination : Environmental Impact and Health Effects, Vol 1 Ann rbor Science Publisher, Inc, Ann Arbor, Mach-439 pp.

Depkes RI, Modul Pelatihan Perbaikan Kualitas Air, Jakarta, Depkes, 1992

Depkes RI, 1993 Petunjuk Pemeriksaan Airminum/ bersih, pusat laboratorium kesehatan Jakarta.

Djasio Sanropie, Ny. Sumini A.R, Margono, Sugihato, Slamet Purwanto, Bambang Ristanto, 1984 Penyediaan Air Bersih Proyek Pengembangan Pendidikan tenaga Sanitasi Pusat, Pusat Pendidikan dan Latihan Pegawai, Dekes RI.

Kusnaedi, 1995. Mengolah Air Gambut dan Air Kotor untuk Air Minum, Jakarta : Penebar Swadaya.

Linsley R.K dan Franzini J. 1991. Teknik Sumber Daya Air. Jakarta : Erlangga.

Riyadi S, 1984. Pencemaran Air Dasar dasar dan Pokok Penanggulangannya. Surabaya : Karya Anda.

Said N.I. 1999. Kesehatan Masyarakat dan Teknologi Peningkatan Kualitas Air, Direktorat Teknologi Lingkungan.

Sanropie D.et. al. 1984. Pedoman Studi Penyediaan Air Bersih, APK-TS Proyek Pengembangan Pendidikan Teknologi dan Sanitasi Pusat.

Sularso, AD. 1998. Penurunan Kadar Fe dan Mn Air Sumur dengan Kombinasi Proses Aerasi dan Saringan Pasir Cepat Perumnas II Tanggerang Jawa Barat. (Skripsi). Yogyakarta : STTI YLH.

Sutrisno dan Suciastuti. 1987, Teknologi Penyediaan Air Bersih, Jakarta : Rineka Cipta.

Slamet Agus dan Masduqi Ali,2000 Satuan Proses Fakultas Teknik Sipil dan Perencanaan Institut Teknologi Sepuluh Nopember Surabaya.

Tjokrokusumo. 1995. Pengantar Konsep Teknologi Bersih Khusus Pengelolaan dan Pengolahan Air. Yogyakarta : STTL YLH.

Hartono. 2008. SPSS 16.0 Analisis Data Statistika dan Penelitian. Yogyakarta : Pustaka Belajar. 